\title{
Atypical Meningioma in a Young HIV Patient
}

\author{
Moataz Abbara ${ }^{\mathrm{a}}$, Abdullah Tolaymat ${ }^{\mathrm{a}, \mathrm{b}}$, Oscar E. Battles ${ }^{\mathrm{a}}$, \\ M. Sami Walida, Joe Sam Robinson ${ }^{\text {a }}$
}

\begin{abstract}
Although intracranial lymphoma is the most common primary intracranial tumor among AIDS patients, we report a 25 years old HIV positive patient with a recent onset of seizures for which he was evaluated with brain scan and was found to have a left frontal lesion with cystic necrotic appearance. Pathological examination confirmed an atypical meningioma WHO grade II. This would be the seventh case in the literature of a meningioma in an HIV positive patient.
\end{abstract}

Keywords: HIV; Meningioma

\section{Introduction}

The Centers for Disease Control and Prevention (CDC) estimates that more than one million people are living with HIV infection in the United States [1]. Although HIV patients are twenty times more likely to develop intracranial lymphoma [2], they may rarely grow other types of intracranial tumors such as meningiomas and gliomas $[3,4]$.

Meningiomas represent $33.4 \%$ of all primary brain tumors, making them the most common primary brain tumors [5]. The prevalence of meningioma is estimated at approximately 97.5 in 100,000 in the United States with over 138,000 individuals currently diagnosed with this tumor [6]. Meningiomas are more common in women $(1: 1.4$ to $1: 2.8$

Manuscript accepted for publication August 25, 2010

${ }^{\mathrm{a}}$ Georgia Neurosurgical Institute, Macon, GA, US

${ }^{\mathrm{b}}$ Corresponding author: Georgia Neurosurgical Institute, Macon, GA, US. Email: tolaymat84@gmail.com

doi:10.4021/jmc40w men to women ratio) and reportedly more common in African Americans [7]. Approximately 90\% of meningiomas are benign, 5-10\% atypical [World Health organization (WHO) grade II] and less than $2 \%$ classified as malignant (WHO grade III, also termed anaplastic) [8]. About 3\% of benign meningiomas and $78 \%$ of atypical tumors recur in five years [9]. The median time to recurrence for benign lesions is 7.5 and for malignant 3.5 years [9].

The current case, to our knowledge, would be the seventh case in the literature of a meningioma in an HIV positive patient $[4,10,11]$.

\section{Case Report}

A 25-year-old African-American male was admitted because of a recent onset of seizures. He had been HIV positive for seven years and he was not on antiretroviral therapy. His past medical history was insignificant. The neurological exam was normal. On admission, the patient had leukocytosis of 16,000 but no fever. His body mass index (BMI) was 16 (weight 106 pounds). Brain MRI showed a $2.2 \times 1.7$ $\mathrm{x} 2.0 \mathrm{~cm}$ irregular enhancing mass in the inferior aspect of the left frontal lobe with surrounding large amount of vasogenic edema. The radiologist suggested a differential diagnosis including anaplastic astrocytoma/glioma, lymphoma,

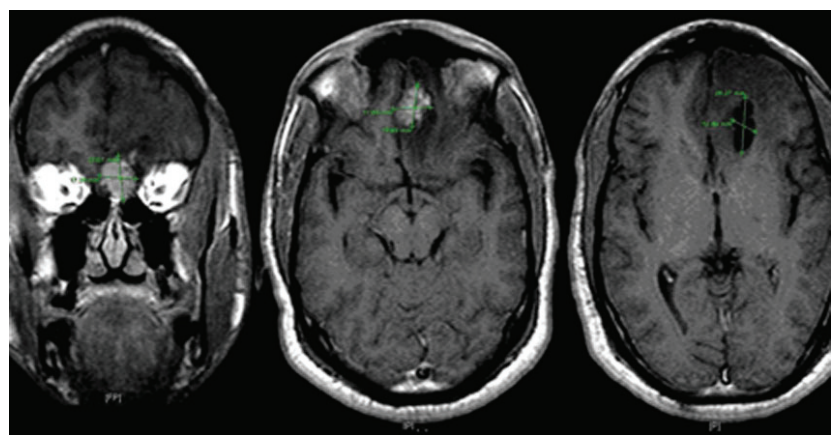

Figure 1. MRI of the brain with contrast showing a necrotic mass with irregular enhancement. 


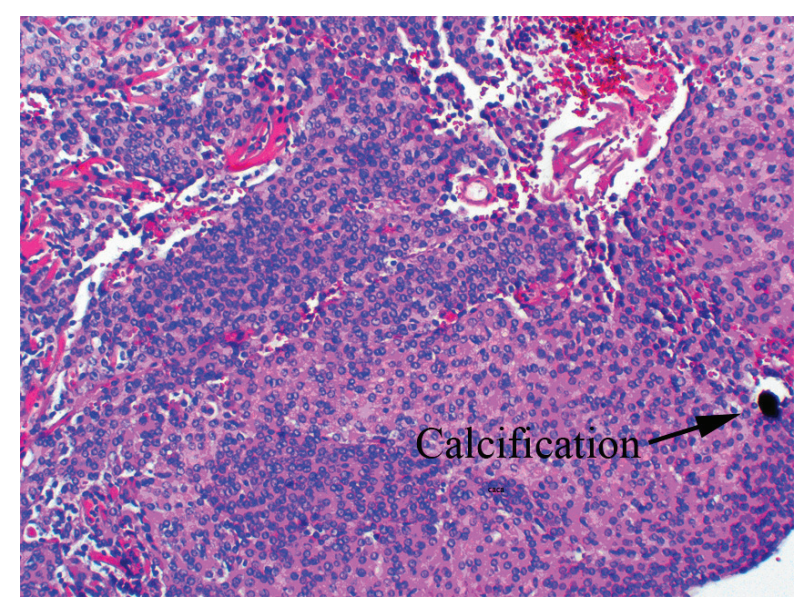

Figure 2. Hematoxylin and eosin (H\&E) showing calcification, 40x.

metastatic disease and less likely squamous cell carcinoma arising from the adjacent ethmoid sinus. There was also an adjacent $1.3 \times 2.6 \mathrm{~cm}$ cystic structure in the left frontal lobe which appeared to communicate with the left lateral ventricle frontal horn (Fig. 1). This, according to the radiologist, more likely represented an incidental porencephalic cyst rather than a component of the mass.

An infectious disease specialist was consulted for suspected microbiologic etiology. Baseline viral load was less than 50 copies/ $\mu 1$ and laboratory tests for toxoplasmosis, cryptococcus and syphilis were negative. Craniotomy was performed and pathology report came with atypical meningioma WHO grade II (Fig. 2 - 4).

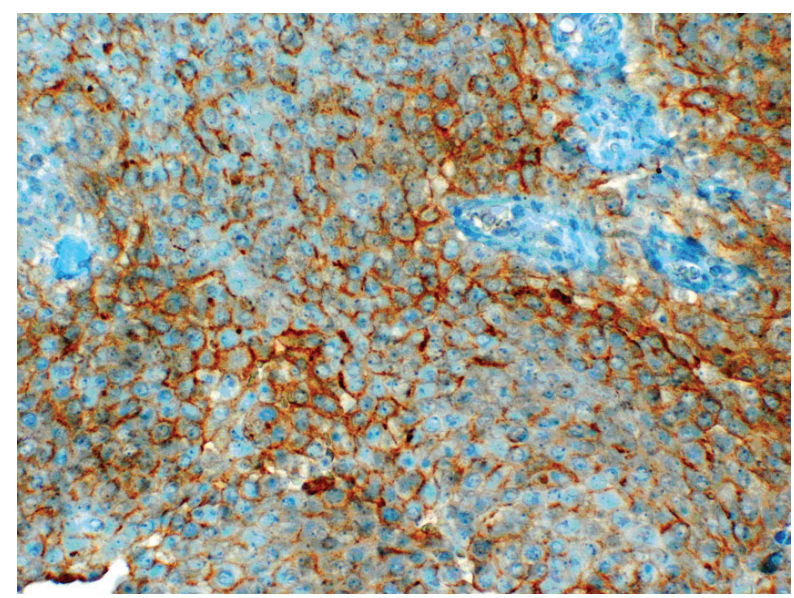

Figure 3. Epithelial membrane antigen (EMA) immunostain showing membrane and cytoplasmic positivity, 200x.

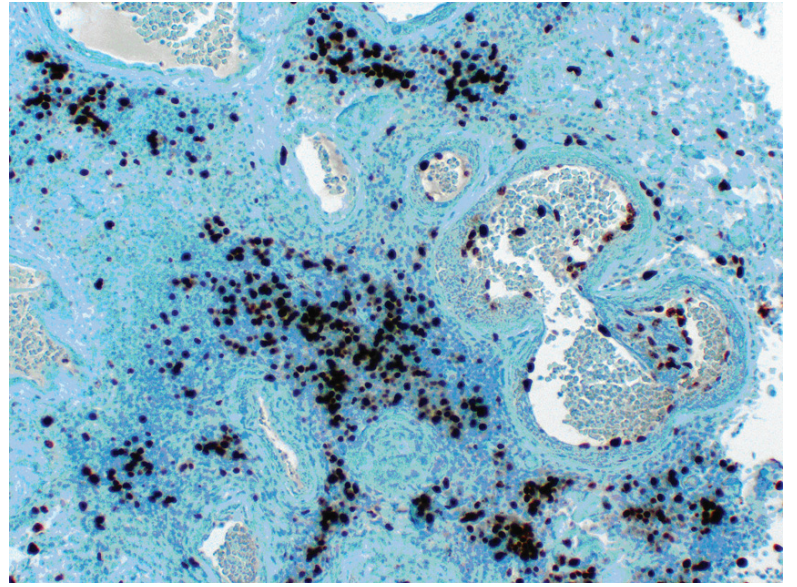

Figure 4. Ki-67 immunostain showing increased proliferation rate (grade II tumor), 200x.

\section{Discussion}

Meningiomas are generally solid tumors but may rarely be associated with cysts resulting in diagnostic difficulties on imaging [12]. In HIV positive patients, not all intracranial cysto-necrotic brain lesions are indicative of an infectious process. They may be a tumor manifestation, including meningiomas. Viral antigens, like HIV tat protein, have been implicated in the pathogenesis of such tumors [13, 14]. These proteins are transcriptional activators that regulate one or more genes by increasing the rate of transcription, It may be that the HIV virus plays an oncogenic role through the occurrence of mutations and especially loss of chromosome 22 on a background of immune deficiency [9]. This case suggests that HIV positive patients may develop higher malignancy meningiomas at an earlier age than in the general population where it occurs usually at age 55 years for atypical meningioma [15]. A previous report by Khurshid et al. 1999 described four HIV patients with meningiomas in which the mean age at diagnosis was 40 [4]. All four patients had solid tumors (meningiomas) and three of them were in advanced HIV stage (AIDS) contrary to our patient. The true prevalence of such cases may be higher than initially thought due to lack of extensive autopsy data on AIDS patients. Larger case series will be required to make more solid conclusions.

\section{References}

1. HIV and AIDS in the United States July 2010. http:// www.cdc.gov/hiv/resources/factsheets/us.htm

2. Mallick I. Primary CNS Lymphoma and HIV/AIDS. November 13, 2006. http://lymphoma.about.com/od/ 
riskfactors/p/cnsaids.htm

3. Blumenthal DT, Raizer JJ, Rosenblum MK, Bilsky MH, Hariharan S, Abrey LE. Primary intracranial neoplasms in patients with HIV. Neurology 1999;52(8):1648-1651.

4. Khurshid A, Joseph JT, Rachlin J, Cooley TP, Kleefield $\mathrm{J}$, Dezube BJ. Meningioma in four patients with human immunodeficiency virus infection. Mayo Clin Proc 1999;74(3):253-257.

5. CBTRUS (2009). CBTRUS Statistical Report: Primary Brain and Central Nervous System Tumors Diagnosed in the United States in 2004-2005. Source: Central Brain Tumor Registry of the United States, Hinsdale, IL. website: www.cbtrus.org

6. Claus EB, Bondy ML, Schildkraut JM, Wiemels JL, Wrensch M, Black PM. Epidemiology of intracranial meningioma. Neurosurgery 2005;57(6):1088-1095; discussion 1088-1095.

7. Haddad G, Turkmani A. Meningioma http://emedicine. medscape.com/article/1156552-overview.

8. Park JK; Black PM; Shih HA. Treatment of meningioma. UpToDate 17.2 2009.

9. Balmaceda CM, Sisti MB, and Bruce JN. Rowland Chapter 54. Tumors of the Meninges. Merritt's Neurol- ogy 10th Edition (June 2000). Lewis P. Rowland (Editor). Lippincott Williams \& Wilkins Publishers.

10. Zeng M, Knisely J. Post-radiotherapy myelitis observed in an AIDS patient with a meningioma: case report and review of the literature. J Neurooncol 1999;45(2):167174.

11. Crosato IM, Tirelli U, Vaccher E, Clerici M, De Lalla F, Faustini M, Gritti F, et al. [Solid tumors associated with HIV infection]. Minerva Med 1993;84(3):89-94.

12. Sridhar K, Ravi R, Ramamurthi B, Vasudevan MC. Cystic meningiomas. Surg Neurol 1995;43(3):235-239.

13. Yung AWK, Janus T. Chapter 46 - Primary Neurological Tumors. Goetz: Textbook of Clinical Neurology, 1 st ed. Christopher G. Goetz (Editor). B. Saunders Company.

14. Tao Y, Wei Q, Xu Z, Bai R, Li Y, Luo C, Dong Y, et al. Holistic and network analysis of meningioma pathogenesis and malignancy. Biofactors 2006;28(3-4):203-219.

15. Aghi MK, Carter BS, Cosgrove GR, Ojemann RG, Amin-Hanjani S, Martuza RL, Curry WT, Jr., et al. Long-term recurrence rates of atypical meningiomas after gross total resection with or without postoperative adjuvant radiation. Neurosurgery 2009;64(1):56-60; discussion 60 . 